be remembered for the legacy of thought and of uncompromising values that he, at the high point of American leadership, articulated with erudition and passion.

Charles F. Doran

Paul H. Nitze School of Advanced International Studies, Johns Hopkins University

\section{Ruth C. Lawson}

Ruth C. Lawson, professor emeritus of political science at Mount Holyoke College, died on December 14, 1990 in Leeds, Massachusetts, at the age of 79 . Ruth was a magna cum laude graduate of Mount Holyoke, and received her master's and Ph.D. degrees from Bryn Mawr. Before returning to Mount Holyoke College as a teacher, Ruth taught at Newcomb College at Tulane University from 1936 to 1942 . During her tenure at Mount Holyoke from 1942 to 1976 , Ruth also directed the Smith College Program in Geneva in 1949-50 and the University of Massachusetts Summer Program in Italy in 1966. After her retirement, Ruth taught at Amherst, Hampshire, and Wheaton Colleges.

Ruth was a specialist in European affairs and international law and organization. Her interests led to extensive foreign travel and study in Geneva, the Hague, and at the Center for Contemporary European Studies at the University of Sussex. Ruth wrote on European security issues and international regional organizations, and published in a variety of professional journals.

But Ruth's passion was in teaching, and she worked incredibly hard to prepare young women to commit themselves to careers in international relations. She organized the United Nations Institutes at Mount Holyoke, bringing together some of the most important theorists and practitioners of the fledgling organization for discussions about its future role. In 1950, Ruth established the International Internship Program, one of the very first such programs in the country. Ruth insisted that her students learn first-hand about the international organizations they had studied in class, and she sent them to bodies such as NATO, the United Nations, and the Organization of American States. Since that time, more than one thousand students have profited from these experiences, and Ruth took great pleasure in recounting the names of her former students who had risen to positions of authority in global organizations. The Internship Program still continues to carry on Ruth's commitment, and this particular part of her legacy remains an outstanding success.

On her retirement in 1976, an annual fellowship program was established in her name, which aids students in graduate study in international relations. In 1988, a conference entitled "Reshaping International Institutions" was held at the United Nations, and many of her former students came together to honor their mentor and inspiration. As a participant in that conference, I was amazed by the depth of love and respect Ruth commanded from her students. Through the efforts of those alumnae, the Ruth C. Lawson Chair in Politics was recently established at Mount Holyoke College.

Ruth gave her life to her family and Mount Holyoke College. She understood that an undergratuate institution was a special place; that it was a college for women gave her commitment a special intensity, particularly since her field was not one that was hospitable to women. Ruth would only accept the best from herself and her students and colleagues. It was this temperament that exasperated some but which stimulated those who loved the challenge to excel.

My own experience with Ruth only suggests the vehemence of her commitment. I first met Ruth at my interview for a position at Mount Holyoke in 1976. It was not any position-it was her position, and my graduate school advisors at MIT had warned me about the intimidating presence of a Miss Lawson. I was thus partially prepared for the piercing stare when asked my analysis of the future of NATO. But only partially. As I frantically tried to compose my thoughts to this terribly open-ended question, another part of me gasped in sympathy and terror for those thousands of students who had undergone similar interrogations.
I have no memory of my response.

I subsequently learned that Ruth challenged everyone in this manner and that I had not been singled out because of some obvious defect in my educational background. And yet, for so many of her students and colleagues, Ruth was a beloved inspiration. We understood that Ruth was simply demanding the best we could offer, and we appreciated her confidence in our ability to comprehend some of the most intractable questions facing humankind in the twentieth century. Ruth did not live long enough to see all her expectations for the global community fulfilled, but she had no doubts that ultimately those hopes would come to pass. And she expects us all to carry on her dreams and legacies.

Vincent Ferraro

Mount Holyoke College

\section{George C. Littke}

George C. Littke, associate professor of political science at California State University, Los Angeles, died February 15, 1991, in Pasadena, California, at the age of 64 . He is survived by his wife, Lael, and daughter Laurie.

Born in 1926, Professor Littke received his B.A. from the University of Utah in 1952 and his Ph.D. from New York University in 1970, where he wrote his dissertation under Louis Koenig. He served as a NASPAA fellow in the Department of Health, Education and Welfare in Washington, D.C. in 1971-1972.

He came to California State University, Los Angeles, in 1963 and spent almost 30 years in university service. At the time of his death, he was a core member of the public administration faculty, offering courses and graduate seminars in community development, public financial administration and budgeting, and intergovernmental relations. He was a specialist in the internal management of governmental and non-profit agencies, as well as emergency management coordination in local government.

His report, entitled "Emergency Disaster Management, Patterns of Inter-City Mutual Aid (Los Angeles County)," was published by the Ed- 